\title{
Insect pathogens and biological toxins in Canadian forestry practice
}

\author{
I believe we can agree that for the forseeable \\ future we will find it necessary to intervene \\ from time to time to protect the forests from \\ damage by insects and that some-but \\ not all-major forest insect problems can be \\ satisfactorily and acceptably solved without \\ creating pollution problems in their stead.
}

Based on a paper read at a meeting of the Champlain Section Canadian Institute of Forestry, at Harrington Forest Farm, 11-12 September 1970 .

\section{J. W. MacBAIN CAMERON}

Contribution No. 178 Insect Pathology Research Institute Canadian Forestry Service Sault Ste. Marie, Ontario
Les agents pathogènes et les toxines dans la pratique de la foresterie canadienne. Des observations renouvelées sur la présence de maladies chez certains insectes, de même que sur les effets de ces dernières dans la diminution des épidémies, ont conduit à la connaissance de moyens susceptibles de rendre ces maladies plus efficaces.

Ce genre de recherche qui s'effectue depuis plus d'un quart de siècle a été entrepris à l'Institut de Recherche sur la pathologie des Insectes du Service Forestier Canadien à Sault-Ste-Marie, Ontario, de même que dans d'autres pays.

Certains résultats prometteurs ont été ainsi obtenus. La bactérie Bacillus thuringiensis, produite commercialement par plusieurs pays est à la base de cet ingrédient actif utilisé pour les préparations insecticides.

Dispendieux à fabriquer, ces produits se trouvent présentement utilisés pour les récoltes agricoles de grande valeur. Toutefois, il a été démontré que ceux-ci parviennent à détruire bon nombre d'espèces de Lépidoptères qui s'attaquent aux arbres. Plusieurs espèces de mouches à scie ont souffert de maladies virales et certaines de ces maladies s'avèrent rentables.

La mouche à scie de l'épicéa, Diprion hercyniae, celle des pins européens, Neodiprion sertifer, incluant la monche à scie à tête rouge, Neodiprion lecontei sont les espèces ainsi contrôlables. La tordeuse des bourgeons de l'épinette se montre affectée par certains virus et les recherches se poursuivent afin de déterminer si cet insecte peut finalement être contrôlé de cette façon.

Les toxines biologiques et les produits pathogènes comportent certains avantages sur les insecticides chimiques:

1/ Ce sont des produits naturels du milieu, qui se rencontrent en grande quantité à la suite de développements d'épidémies de sorte qu'ils ne peuvent être considérés en tant que polluants comparativement aux produits chimiques.

2/ Ils semblent sans effet nocif à l'homme ou aux animaux supérieurs et n'offrent aucun risque.

3/ Ils ne nuisent pas à l'action des parasites et prédateurs, fournissant ainsi un apport positif dans la lutte contre les insectes nuisibles.

4/ Ils présentent une possibilité (notamment les virus) de maintenir un équilibre permettant de contrôler l'insecte à un niveau relativement bas sans nécessité de traitements annuels.

Il va sans dire que tous les insectes ne sont pas sensibles à ces moyens de lutte; par contre lorsque des résultats valables auront été obtenus, l'utilisation des produits pathogènes devrait être envisagée en remplacement des produits insecticides.
The first record of the recognition of disease in insects is credited to Aristotle, and the first complete description of such a disease was published in 1527. Nevertheless the study of these diseases and their potential use in insect control is comparatively recent. A little over a century ago Pasteur was assigned by the government of France to find the cause of and cure for a disease that was threatening ruin to the silk industry. He was successful in doing so, and showed that the disease was caused by a protozoan and that it could be controlled by sanitation. This incidentally was the beginning of Pasteur's work - he had been trained as a chemist - that led to the development of the modern discipline of bacteriology. Shortly afterwards certain Russian workers became involved in a study of insect diseases, especially those caused by fungi (Metchnikoff 1879), and actually established a plant for production of spores to be distributed on crops to protect them from insect attack (Krassilstschik 1886). In 1915 d'Herelle, on the basis of experiments performed in Mexico, proposed that bacteria should be used to control grasshoppers.

This early interest in the possibilities of using disease for controlling insect pests was no doubt due to repeated observations that massive outbreaks were often very quickly eliminated by natural occurrence of epizootics. It was quite natural to assume that if such an epizootic could be initiated at will, a very powerful tool for crop protection would be available. But despite numerous attempts to develop the method, success was unpredictable.

The work of Bird (1944) following the collapse of the outbreak of spruce sawfly, Gilpinia hercyniae, in New Brunswick and Gaspé marked the beginning of the present program of insect pathology research. In 1946 the nucleus of the present Insect Pathology Research Institute was assembled in Sault Ste. Marie, and in the same year the late Edward A. Steinhaus established the Laboratory of Insect Pathology at the University of California in Berkeley. In both centres attention was devoted mainly to 
obtaining answers to fundamental questions in insect pathology, although practical aspects were not neglected. In 1949 Steinhaus and Thompson reported the use of polyhedrosis virus to control the alfalfa caterpillar, Colias philodice eurytheme (Steinhaus and Thompson 1949). In 1950 Bird began a three-year program of field testing of virus against the European pine sawfly, Neodiprion sertifer (Bird 1953), and in 1951 Steinhaus proposed that the bacterium Bacillus thuringiensis could be used to control alfalfa caterpillar (Steinhaus 1951). Since that time research has continued and has been taken up in many other countries as the possibilities and advantages of this approach to insect regulation have been recognized.

At the Institute, most of our field research on diseases of forest insects has been done in plantations, because the working conditions are much easier and more uniform, and because it is much easier to see what happens to the insects. Also, since only one pathogen is presently available in quantities for application over large areas, it has been necessary to be very frugal in distributing the pathogens, taking care to use them only where the maximum information could be obtained. We are hopeful that the success so far attained will encourage development of production facilities so that larger experiments, designed to measure economic potential, can be planned, and eventually that useful pathogens can be made available in large quantities for distribution over forested areas.

The pathogens that at the present time appear to have the greatest potential as regulating agents for forest insects are the viruses. The infectious agent is a minute rod-shaped or spherical body of dimensions measured in fractions of a micron. Like the viruses of higher animals, they are obligate parasites and multiply in the cells of the host. They are usually enclosed in a protective coating of protein, and there may be one to many virus particles in each inclusion body. The size and shape of the inclusion body (called the polyhedron) are usually distinctive, and may be used to diagnose the presence of virus. The viruses are truly infectious, and will spread from individual to individual just as do diseases of higher animals. For this reason it is not as necessary that total coverage of the crop be obtained. The insect viruses are highly host specific, and experimental results show that once an infection by a virulent virus has been initiated in a population it will spread more or less rapidly wherever the host insect is present above a minimum density. Some of the evidence is very striking.

In his early work with the virus of European pine sawfly, Neodiprion sertifer, Bird (1953) made a suspension of the body contents of virus-killed larvae in water, at a concentration of about $4,000,000$ polyhedra in each millilitre of suspension. It was blown as a mist and allowed to drift with the breeze over a sawfly-infested plantation of Scots pine. First mortality occurred in about a week, and after 11 days colonies containing dead larvae were found about $\mathbf{2 0 0}$ feet from the spray point. When a much

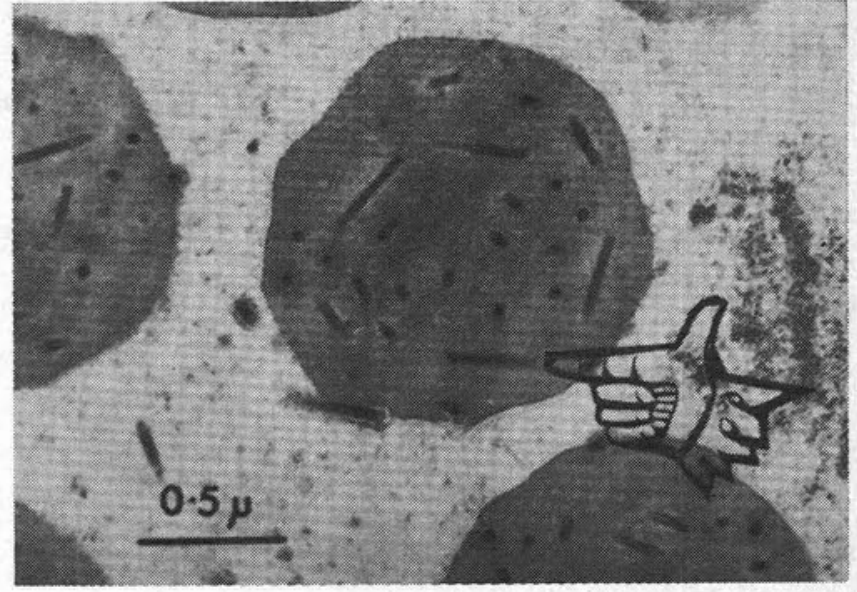

Electron micrograph of a section of the nucleus of a cell of the white-marked tussock moth infected by polyhedrosis virus. Note that in this virus the virions (the infective particles) one is indicated - occur singly embedded in the polyhedron (dark area) which is composed of non-infectinus protein. (Courtesy J. C. Cunningham.)

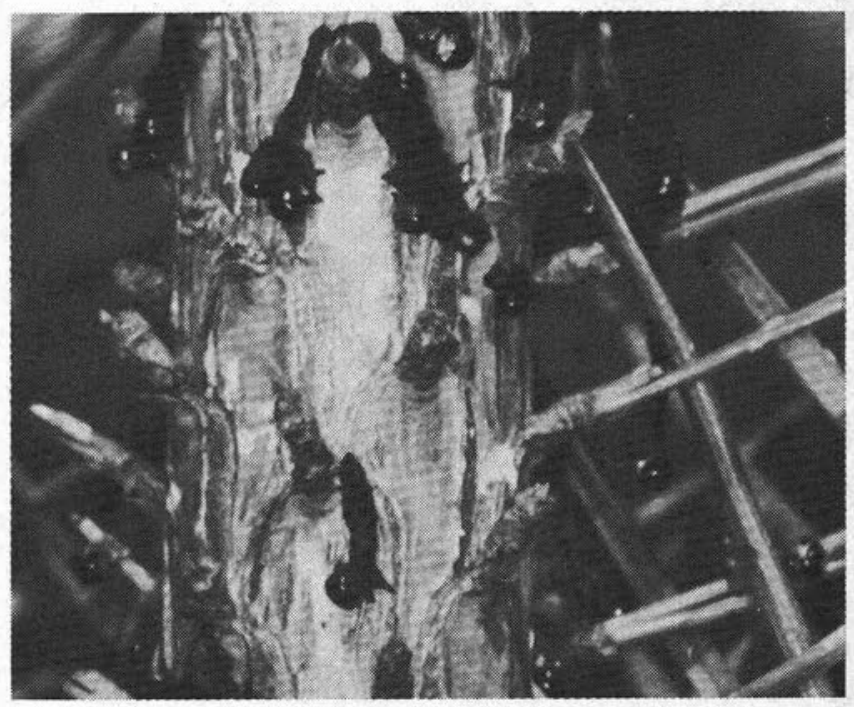

Larvae of a Neodriprion sawfly killed by a virus. Insects such as these can be collected as a source of inoculum for spraying on infected trees. (Courtesy F. T. Bird.)

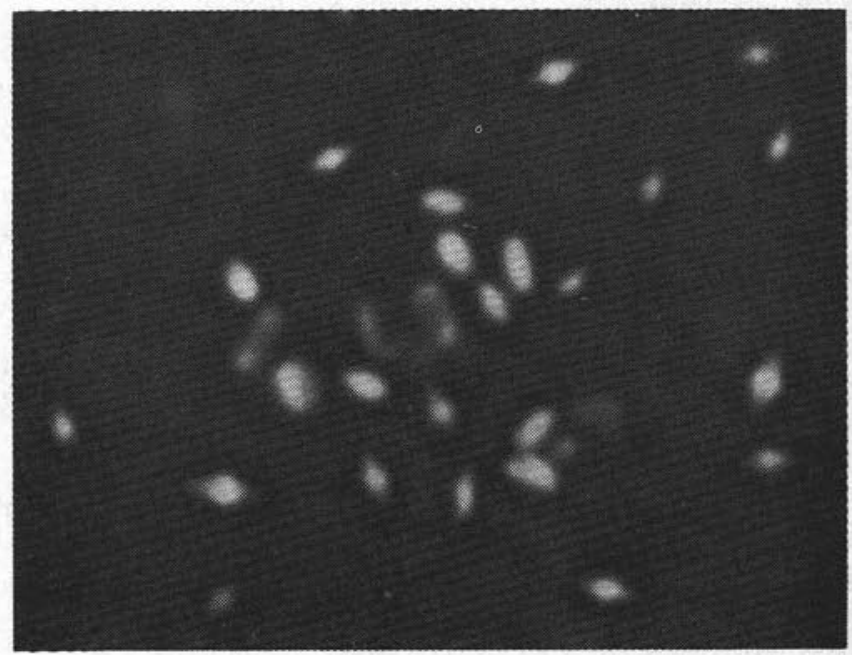

Photomicrograph showing spores and the diamond-shaped toxic crystals produced by the bacterium Bacillus thuringiensis. (Courtesy T. A. Angus.) 
heavier concentration, $20,000,000$ polyhedra per millilitre, was used, the spread was at least 900 feet after $\mathbf{2 7}$ days. In still another test about a half-gallon of virus suspension was sprayed by mist blower in one corner of an infested 100-acre plantation By the end of the next season disease was found over about one-third of the plantation, and the following year it spread throughout the entire 100 acres and created a severe epizootic (Bird 1961).

Since 1954 we have had a cooperative arrangement with the Ontario Department of Lands and Forests for the production and distribution of this virus. Each year large numbers of larvae are collected as they reach the fourth instar, and are allowed to feed on foliage that has been sprayed with a suspension of the virus. They begin to die in 7 or 8 days and the dead are collected and sent to the Institute for processing. At first this was done by placing the larvae in water and leaving them until they were completely decomposed. The polyhedra were then separated and washed, and a standardized concentrate was prepared, to be appropriately diluted when used. Recently a new technique has been developed; the dead larvae are placed in a deep-freezer as they are collected, and then the frozen material is transferred to a freezedryer. When completely dry, the material is reduced to a powder which again is standardized for virus concentration, and an appropriate amount is suspended in water for spraying. This method is quicker and results in less loss of infectious material.

Other insects also are susceptible to virus infection. For example, outbreaks of the sawfly Neodiprion lecontei have been controlled on several occasions by spraying virus on infested plantations. A demonstration of the technique was given in 1970 in a small plantation near St. Jovite, Quebec, in a district where there had been widespread and heavy defoliation during the past three or four years. In the treated area there was a heavy population and severe defoliation and tree mortality would have occurred. Application of the virus resulted in virtual elimination of the insects. This is a very effective virus, prepared now by the freeze-drying method referred to above, and we now have sufficient quantities on hand for treatment of extensive areas should this be required in future years. As with all pathogens, treatment should be applied as soon as increase of the pest becomes apparent, in order to prevent damage.

It should be pointed out that there are two approaches to using viruses. Ideally the aim will be to introduce the virus and have it spread and establish a balance in the population such that there are always enough insects to maintain the virus pool but not enough to cause economic damage. Such a situation actually occurs, due to the virus alone or to a combination of virus and parasites, in the European spruce sawfly (Bird and Burke 1961). Alternatively, when necessary a virus can also be used in the same way as a chemical insecticide, applying a uniform dosage over the whole infested area. This was done some years ago when a heavy outbreak of European pine sawfly was controlled in plantations throughout Manitoulin Island, Ontario. Since that time the population has remained at a very low level, and no further control measures have been required.

We have not neglected the spruce budworm in our research program, but it has been a most difficult problem. It actually is host to four different virus diseases, which in the early research could not be easily separated and it was difficult to interpret the results of experimentation. Recently pure preparations of two of these viruses have been produced, and a program of field investigation has been carried on during the past two seasons. Bird (1970) demonstrated that both viruses are reasonably infectious and that they can be introduced into populations of the budworm. We have not had an opportunity yet to determine how much practical value this may have in terms of treating large forested areas, but we are currently producing the virus on a small scale and hope that in 1971 there will be enough on hand that we can organize an operational experiment to determine whether we are even close to practicality. It will still require a great deal of investigation to determine the best method for application, the carrier to be used, ways to prevent or at least reduce loss of infectivity after application, and other similar problems.

The situation regarding bacterial pathogens is rather different. Although one or two species are host specific, notably Bacillus popilliae used to control the Japanese beetle in the northeastern United States, a single species is the basis for most of the work with this group. The species is Bacillus thuringiensis, and it occurs as a number of varieties with slight but biologically or chemically recognizable differences. Some ten or so of these varieties have been shown to affect insects (Angus 1968), and it is beginning to appear probable that the larvae of most Lepidoptera - i.e., the moths and butterflies - are susceptible. So far members of other orders - flies, beetles, bees, etc. — do not appear to be affected.

This organism is now produced and sold commercially in several countries in Europe as well as in the United States. The total annual production probably amounts to several thousand tons. It is widely used for controlling caterpillars on truck crops, because it does not affect higher animals and therefore there is no problem of a residue tolerance level as there is with chemicals; if necessary it can be used right up to the time of harvest. We know that a considerable number of pest or potential pest insects in the forest are susceptible also, and we are presently attempting to determine whether the bacterium can be used economically for regulating populations.

In one sense it is perhaps not strictly correct to refer to $\mathbf{B}$. thuringiensis as a pathogen, since in many cases it acts like a poison and does not spread from one individual to another. As the organism grows and develops through its normal cycle in an artificial medium, it passes through a phase of rapid multiplication known as the vegetative phase bacteriologists also refer to it as the logarithmic 
phase because multiplication is by simple cell division resulting in repeated doubling of the cell population. After some time the vegetative process ceases, and instead of a new pair of vegetative cells a spore is formed. This is accompanied by the formation of a parasporal body (Angus 1956). The parasporal body usually is diamond-shaped in silhouette; chemically it is a proteinaceous substance, and it is very highly toxic for many insects, in some cases at least the same order of toxicity as DDT. When fed to susceptible insects it results very quickly in paralysis that causes cessation of feeding, and many of the insects lose their ability to cling and drop to the ground where they eventually die. Even though they may remain alive and on the plant for up to several days, no feeding takes place and so there is no further damage.

We in our Institute, as well as many other scientists throughout the world, have been studying these bacteria during the past 20 years or so. As our knowledge has accumulated we have tried to use them for insect control. They are now widely used on agricultural crops but the cost has been such that so far no extensive applications to forests have been attempted. We have made aerial applications against spruce budworm on two occasions, in 1960 and again in 1969, using commercially produced material. In both cases it was demonstrated that the material applied to forest trees can kill the budworm. On the first occasion it was quite evident that additional basic research was needed in order to approach practicality. It was applied in an oil carrier, without enough time to find one with suitable characteristics, and deposition was not satisfactory. In 1969 a water suspension of an improved concentrate was used, but apparently the fine mist generated at the nozzles evaporated before it reached the trees and the dry material did not adhere well. Nevertheless, in those parts of the plot where there was a reasonably satisfactory deposit as shown by indicator cards and by analysis of spore deposition on the foliage, a significant proportion of larvae were killed. At least one manufacturer is now working on the development of a formulation specifically designed for application to coniferous forests.

Knowing from laboratory tests that the spruce budworm is highly susceptible, and that the problem therefore is to get the pathogen to it, a series of single-tree tests was set up in 1970, using two commercial preparations. Spray was applied, to small trees using a compressed air sprayer. The first application was on May 1, just after the larvae emerged from hibernation and while they were feeding as needle miners. Additional trees were sprayed at approximately weekly intervals until June 17, an estimated five days before pupation would begin. Ten previously untreated trees were sprayed each time, so that results at the end of the season represented the effect of a single application each at a different stage of larval development.

Both formulations appear to be effective. Larvae sprayed during the needle-mining stage were found dead in the needles and were positive for $\mathbf{B}$. thuringiensis. Spray applied while the larvae were feeding in the unopened buds was less effective, although some mortality was noted. The rate of mortality increased markedly when spray was applied after the bud-caps were shed. Early sprays were quite effective in reducing bud damage, later ones less so. Population reduction, indicated by counts of late larvae and pupae, varied from 50 to over 95 per cent, depending to some extent on the time of application. It must be emphasized that these results were obtained by very heavy spraying and do not necessarily indicate that an operational application would do as well. Further work on improving formulation is necessary, to be followed by tests to determine the proper dosage rate, the optimum time for application, and finally direct comparison with chemical pesticides applied to a large area of infested forest.

Having spent so much time on specifics of viruses and bacteria, let us now turn to the immediate theme - Forestry and Pollution. I believe we can take as agreed that for the foreseeable future we will find it necessary to intervene from time to time to protect the forests from damage by insects, and it is increasingly apparent that the public will not condone large-scale distribution of chemical insecticides as has been common in the past. Even the new ultra low volume applications will be criticized because of the potential cumulative effect.

What are alternative solutions to the problem of pest regulation? I submit that use of pathogens is one that must be seriously considered, and that even though the first cost may appear to be greater than that of chemicals, the ultimate results may be more economical; and even if this is not the case, the lack of undesirable or unacceptable side effects may well be worth at least some higher cost. My reasons for offering this course are as follows:

1/ No insect pathogen has yet been developed de novo. All have been recovered from insects that had died naturally. Therefore they cannot be considered a pollutant in the sense that a manufactured chemical such as DDT is.

2/ For well over a century, and particularly during the past twenty years, many hundreds of individuals have been involved in research on insect diseases, yet none has ever reported suffering ill effects of any significance. There have been a few cases of minor reactions resembling allergies in individuals, but certainly no infections or deaths.

3/ From time to time extremely heavy insect outbreaks, such as those of grasshoppers on the prairies and farm lands, or tent caterpillars in the forests, have been naturally controlled largely or entirely by disease. Such a condition inevitably leaves in the immediate environment amounts of the pathogen many hundreds of times more concentrated than could ever be applied artificially as an inoculum, yet no cases of ill effects attributable to such a pathogen have ever been reported. It therefore seems evident that to use these pathogens in a control operation can not be considered to present any significant hazard. 
4/ All research so far indicates that effective viruses that might be developed for use in insect regulation are very highly host specific, causing disease in only one or at most a few very closely related insect species and not in any other form of life. Active virus has often been recovered from droppings of birds and small animals that have fed on diseased insects, but the animals showed no evidence of ill effects, and there is good evidence that in many cases parasites are effective distributors of the virus while themselves remaining unharmed.

5/ Bacilus thuringiensis, which is the basis of the only bacterial bioinsecticide so far developed commercially on a large scale, affects, at the levels recommended for use, almost exclusively insects of the order Lepidoptera. Thus parasites and predators, most of which belong to other orders, will not be harmed. (This of course also applied to viruses because of their host specificity).

6/ Reduction of the host by direct action of the pathogen, without an accompanying reduction of effectiveness of the latter can be greatly increased. Thus they may very quickly reach a

\section{Literature cited}

ANGUS, T. A. 1956. General characteristics of certain insect pathogens related to Bacillus cereus. Can. J. Microbiol. 2: $111-121$.

1968. The use of Bacillus thuringiensis as a microbial insecticide. World Rev. Pest Control 7(1): 11-26.

BALCH, R. E. and F. T. Bird. 1944. A virus disease of the European spruce sawfly, Gilpinia hercyniae (Htg.) and its place in natural control. Sci. Agr. 25: 65-80.

BIRD, F. T. 1953. The use of a virus disease in the biological control of the European pine sawfly, Neodiprion sertifer (Geoffr.). Can. Entomol. 85: 437-446.

1961. Transmission of some insect viruses with particular references to ovarial transmission and its importance in the development of epizootics. J. Insect Pathol. 3: 352-380.

BIRD, F. T. and J. M. BURKE. 1961. Artificially disseminated virus as a factor controlling the European spruce sawfly, Diprion hercyniae ( $\mathrm{Htg}$. ) in the absence of introduced parasites. Can. Entomol. 93: 228-238.

BIRD, F. T. and J. R. McPHEE. 1970. Susceptibility of spruce budworm, Choristoneura fumiferana Clemens, to a nuclear level such that further human intervention will be unnecessary, at least for very considerable intervals. If in addition the pathogen spreads rapidly through the pest population, as has been demonstrated in at least some of the viruses, the final level of the pest may be completely innocuous. If this situation can be predicted as likely to occur in a particular case, considerably higher costs of initial application can be justified because future expenditures will be greatly reduced.

Unfortunately, after more than twenty years of concentrated research we are not yet in a position to provide prescriptions for many major forest insect problems. Nevertheless the demonstrated practical successes, and the results of current research, are such as to encourage belief that there is much greater potential than we have yet been able to realize. Further research, and some policy decisions, are necessary - for example, to determine the best way to produce and distribute effective pathogens. But given these, I believe that some - not all major forest insect problems can be satisfactorily and acceptably solved without creating pollution problems in their stead.

polyhedrosis virus sprayed on infested trees. Can. Dep. Fish. Forest. Bi-Mon. Res. Notes 26: 35.

d'HERELLE, F. 1915. Sur le procédé biologique de destruction des sauterelles. Compt. Rend. Acad. Sci., Paris, 161: 503-505.

KRASSILSTCHIK, I. M. 1888. La production industrielle des parasites végétax pour la destruction des insectes nuisibles. Bull. Sci. France 19: 461-472.

METCHNIKOFF, E. 1879. Diseases of the larvae of the grain weevil. Insects harmful to agriculture (series).Issue III, The grain weevil. Published by the Commission attached to the Odessa Zemstvo office for the investigation of the problem of insects harmful to agriculture. Odessa $32 \mathrm{p}$.

STEINHAUS, EDWARD A. 1951. Possible uses of Bacillus thuringiensis Berliner as an aid in the biological control of the alfalfa caterpillar. Hilgardia 20: 359-381.

STEINHAUS, EDWARD A. and CLARENCE G. THOMPSON. 1949. Preliminary field tests using a polyhedrosis virus to control the alfalfa caterpillar. J. Econ. Entomol. 42: 301-305.

\section{EDWARD}

\section{FELLOWS}

\section{FORESTRY \& FOREST PRODUCTS CONSULTANT}

P.O. Box 354, 461 King St., FREDERICTON, N. B.

Registered Professional Forester (N. B.)

anadian Institute of Forestry

Forest Products Research Society, Etc.

INDUSTRY DEVELOPMENT - FOREST PRODUCTS ECONOMIC FOREST POLICY \& ADMINISTRATION

\section{F O REST A L}

FORESTRY AND ENGINEERING INTERNATIONAL LIMITED

F O RESTA L

FORESTRY AND ENGINEERING LIMITED
VANCOUVER 5, CANADA 1409 WEST PENDER STREET Tel.: 683-6994 